Egyptian Journal of Rabbit Science, 22 (1) 23-39(2012)

\title{
INFLUENCE OF SUPPLEMENTATION OF POMEGRANATE DRIED WASTE AS OF NATURAL ANTIOXIDATIVE POTENTIAL SOURCE IN FEEDING DOES RABBITS ON SOME PRODUCTIVE AND REPRODUCTIVE PERFORMANCE, UNDER HOT CLIMATE CONDITION
}

\author{
A. A. Azoz and M. Basyony \\ Animal Production Research Institute, Agricultural Research Center, Dokki, \\ Giza, Egypt.bakrazoz@yahoo.com
}

This study was carried out to investigate the effect of pomegranate dried waste (PDW) supplementation as natural antioxidant source on some reproductive and productive traits and blood constituents' doe rabbits, during summer season in Egypt.

Twenty eight of New Zealand White (NZW) does aged 6 months with an average weight of $2942.5 \pm 48.14 \mathrm{~g}$ were used from April and lasted 16 weeks with 7 does per treatment groups and allotted into four dietary groups. First group was served as control, while, $2^{\text {nd }}, 3^{\text {rd }}, 4^{\text {th }}$ groups were fed control diet with levels 0.5, 1.0 and 1.5\% PDW, respectively.

Results indicate that PDW levels at 0.5, 1.0 and 1.5 with a few exceptions were ranked first, second and third as had the highest values for feed intake during pregnancy $(P<0.01)$, and lactation periods $(P<0.05)$, litter size at birth $(P<0.01)$ and weaning $(P<0.05)$, litter weight at weaning $(P<0.05)$, milk production $(P<0.01)$ through 4 weeks of lactation, while it was lowest values of and pre weaning mortality rate $(P<0.0001)$ during birth to weaning age.

Doe rabbits receiving $0.5,1.0$ or $1.5 \%$ levels of PDW had a significant decrease in blood triglyceride (TG), low density lipoprotein $(L D L)$ and very low density lipoprotein $(v L D L)$. The activities of different blood plasma enzymes were significantly enhanced. Interestingly, PDW levels increased both the blood plasma antioxidant enzymes (TAC, SOD and $G P x$ ).

These results may indicate that dietary supplementation of PDW could be used up to $1.0 \%$ to have a favorable effect in the improvement of doe rabbits performance and antioxidant status during summer season in Egypt.

Keywords: Pomegranate dried waste (PDW), blood lipid profile, antioxidant, reproductive, productive, doe rabbits. 
Oxidants (reactive oxygen species; ROS) are normally generated during cell metabolism and are indispensable for the cellular redox regulation (Kobayashi et al., 2001), supporting the phagocytosis of invading microorganisms (Castellini etal., 2000), and as a key signal molecules in physiological processes, such as oocyte maturation and fertilization, pregnancy and parturition (Kirschvink et al., 2007). Exposure to metabolic, environmental, photo, drug-dependent or nutritional oxidative stress can disturb normal cell functions, initiating chain reactions that can compromise cell integrity (Lykkesfelt and Svendsen, 2007). To counteract, a series of defense mechanisms, one of which are the antioxidants defenses, has been developed (Cheeseman and Slater, 1993).

Pomegranate peel (waste product of the pomegranate industry) was higher antioxidant levels than the juice itself, an attractive candidate as a nutritional supplement for rabbit feed. The mode of action for pomegranate peel extract had high antioxidant capacity, considering the scavenging or preventive capacity against super oxide anion, hydroxyl and peroxyl radical, as well as, inhibiting. Pomegranate fruit peel exerted diverse pharmacological functions as antioxidant activity (Li, Yunfeng et al., 2006 and Thring et al., 2009).

However, in recent years, many attempts have been made to study natural antioxidants, particularly those of plant origin. Pomegranate contains 2, $92 \pm 0,19$ $\mathrm{mg} / 100 \mathrm{~g}$ total phenols and $0.2-1.0 \%$ soluble phenols (Aviram and Dornfeld, 2001) showing remarkable antioxidant activity and significant health properties.

In Egypt, the climate is characterized by a long hot period during the year seasons. Exposure of the growing rabbits to high ambient temperature impairs their growth and increases the mortality rate. Rabbits in hot climate months are very susceptible to heat stress, since they have unfunctional sweat glands and have difficulty in elimination body heat (Marai et al., 1996 \& 2002; Fernandez et al., 1994 and Finzi et al., 1994).

Therefore, the aim of this study was to evaluate the effect of pomegranate dried waste (PDW) supplementation as natural antioxidant source on some reproductive and productive traits and blood constituents' doe rabbits, during summer season in Egypt.

\section{MATERIALS AND METHODS}

The present study was carried out at Borg El-Arab Experimental Station, Animal Production Research Institute, Ministry of Agriculture, Egypt, it was started in April, 2011 and lasted 16 weeks. 
Rabbitry minimum and maximum temperatures, relative humidity and temperature humidity index (THI) during the experimental period were 26.5 $32.5^{\circ} \mathrm{C}, 62-75 \%$ and 87.5 - 93.5, respectively, under Borg El-Arab Experimental Station, Alex., Egypt.

Preparation of fruit wastes (Pomegranate by-product) was taken, washed carefully with running water till being completely clean. They were then dried in an air circulating oven regulated at a temperature of $60{ }^{\circ} \mathrm{C}$ until complete dryness. The dry matter was then ground in a mixer to fine powder and then kept in clean dry containers till used.

In this respect, twenty eight primiparous New Zealand White (NZW) doe rabbits, aged 5-6 months with an average initial body weight, $2942.5 \pm 48.14 \mathrm{~g}$ were randomly divided into four comparable groups. All rabbits were fed on a basal pelleted ration. The $1^{\text {st }}$ group was used as control, while the $2^{\text {nd }}, 3^{\text {rd }}$ and $4^{\text {th }}$ groups were supplemented with $0.5,1.0$ and $1.5 \%$ PDW levels to each doe group, respectively. Twelve fertile bucks (6-7 months of age) were used for mating; however they fed on control diets.

Mating was carried out at random between does and bucks and each doe was transformed to the buck's cage to be mated and returned back to its cage after mating. Each doe was palpated 10 days thereafter to detect pregnancy. Those, which failed to conceive, were returned to the same mating-buck at the day of test.The experimental rabbits were allotted in a windowed house. Flat desk cages $(60 \times 55 \times 40 \mathrm{~cm})$ provided with galvanized nests for does, feeders and drinker nipples. All kindling kits were remained in the nests with their dams for suckling from birth up to weaning at 28 days of age.

All animals were kept under the same environmental and managerial conditions. The basal ration was formulated in one of feed mills to meet the nutrient requirements of rabbits according to NRC (1977). The ration was offered to rabbits ad libitum. Concentrations of total phenolics (TP) in pomegranate peel extracts were determined by the Folin-Ciocalteu colorimetric method (Singleton and Rossi., 1965) at Food Chemistry Department, Wageningen University, Netherland. The ingredients and chemical composition of the pelleted ration and pomegranate by-product are shown in Tables 1and 2. The samples of pelleted ration and pomegranate by-product were analyzed for crude protein $(\mathrm{CP})$, crude fiber (CF), ether extract (EE), nitrogen-free extract (NFE) and ash according to A.O.A.C.(2003).

Feed intake, litter size, litter weight $(\mathrm{g})$ at birth and weaning, and milk production at $1^{\text {st }}, 2^{\text {nd }}, 3^{\text {rd }}$ and $4^{\text {th }}$ week of age were recorded weekly as the method described by Lukefahr et al. (1983). 
Table 1: Formulation and chemical analyses $(\%)$ of the experimental diets.

\begin{tabular}{|c|c|c|c|c|}
\hline \multirow[b]{2}{*}{ Ingredients } & \multicolumn{4}{|c|}{ Pomegranate dried waste in the diet levels (\%) } \\
\hline & $\begin{array}{c}\text { Control } \\
(\mathbf{0 . 0})\end{array}$ & 0.5 & 1.0 & 1.5 \\
\hline Alfalfa hay & 34.55 & 34.05 & 34.05 & 34.05 \\
\hline Wheat bran & 32.00 & 32.00 & 31.50 & 31.00 \\
\hline Barley grain & 12.00 & 12.00 & 12.00 & 12.00 \\
\hline Soybean meal (44\%) & 16.00 & 16.00 & 16.00 & 16.00 \\
\hline Molasses & 3.00 & 3.00 & 3.00 & 3.00 \\
\hline Pomegranate Dried waste & 0.00 & 0.50 & 1.00 & 1.50 \\
\hline Limestone & 1.50 & 1.50 & 1.50 & 1.50 \\
\hline Sodium chloride salt & 0.35 & 0.35 & 0.35 & 0.35 \\
\hline Dl- Methionine & 0.20 & 0.20 & 0.20 & 0.20 \\
\hline L-Lysine & 0.10 & 0.10 & 0.10 & 0.10 \\
\hline Vit, and Min. mix. ${ }^{1}$ & 0.30 & 0.30 & 0.30 & 0.30 \\
\hline Total & 100 & 100 & 100 & 100 \\
\hline \multicolumn{5}{|l|}{ Calculated analysis } \\
\hline Dry Matter & 88.15 & 88.14 & 89.03 & 89.10 \\
\hline Organic Matter & 91.51 & 91.49 & 91.47 & 91.45 \\
\hline Crude Protein & 18.15 & 18.11 & 18.03 & 18.00 \\
\hline Ether Extract & 2.68 & 2.66 & 2.67 & 2.67 \\
\hline Crude Fiber & 15.22 & 15.19 & 15.35 & 15.41 \\
\hline Nitrogen Free Extract & 52.10 & 52.18 & 53.25 & 53.02 \\
\hline $\mathrm{NDF}$ (calculated $)^{2}$ & 38.92 & 38.90 & 39.01 & 39.05 \\
\hline Ash & 8.77 & 8.77 & 8.76 & 8.76 \\
\hline $\mathrm{DE}(\mathrm{Kcal} / \mathrm{Kg})^{*}(\text { calculated })^{3}$ & 2449 & 2450 & 2445 & 2443 \\
\hline
\end{tabular}

(1)=Each 3 kilogram of Vit+Min mixture provides: Vitamin A, $12000 \mathrm{IU}$; Vitamin E, $20 \mathrm{IU}$; Menadione, $1.3 \mathrm{mg}$; Vit. D3, 2500 ICU; Riboflavin, $5.5 \mathrm{mg}$; Ca Pantothenate, $12 \mathrm{mg}$; Nicotinic acid, $50 \mathrm{mg}$; Choline chloride, $600 \mathrm{mg}$; Vitamin B $12,10 \mu \mathrm{g}$; Vitamin B 6 , $3 \mathrm{mg}$; Thiamine, $3 \mathrm{mg}$; Folic acid, $1.0 \mathrm{mg}$; d-biotin, $50 \mu \mathrm{g}$. Trace mineral (milligrams per kilogram of diet): $\mathrm{Mn}, 80 ; \mathrm{Zn}, 60 ; \mathrm{Fe}, 35$; $\mathrm{Cu}, 8 ; \mathrm{Se}, 0.60$.

**Based on NRC (1977).

$(2,3)=\mathrm{DE}(\mathrm{Kcal} / \mathrm{Kg})=4.36-0.0491 \times \mathrm{NDF} \%$, Where, $\mathrm{NDF} \%=28.924+0.657 \times \mathrm{CF} \%$. as calculated according to Cheeke (1987).

Blood samples were collected from the ear vein of each doe rabbit treatment group every week (7 Rabbit's $\times 4$ Weeks), during lactation period and immediately placed on ice in heparinized tubes. Plasma was separated from the blood by centrifugation at $860 \mathrm{rpm}$ for $20 \mathrm{~min}$. and stored at $-60^{\circ} \mathrm{C}$. Blood plasma samples were analyzed biweekly for total cholesterol, HDL- cholesterol, 
Table 2. Chemical composition of pomegranate dried waste, PDW (g/kg DM).

\begin{tabular}{|l|c|}
\hline Nutrient groups & PDW \\
\hline Organic matter & 86.6 \\
Dry matter & 90.2 \\
Crude Protein & 9.60 \\
Ether Extract & 2.61 \\
Crude Fiber & 17.4 \\
NDF & 44.29 \\
Ash & 13.4 \\
Nitrogen free extract & 60.59 \\
Digestible Energy (Kcal/ Kg) & 2185 \\
Total phenolic content: $\mathrm{mg}$ gallic acid equivalents /g dry weight & 270 \\
\hline
\end{tabular}

triglycerides (TG) calorimetrically using commercial kits (Diamond Diagnostics, Egypt). The concentration of Very Low Density Lipoprotein V LDL-c was estimated according to the Fridewald's equation (Fridewald et al., 1972). Thiobarbituric acid-reactive substances (TBARS) were measured in the blood plasma using the method of Tappel and Zalkin (1959). Blood plasma glutathione peroxidase (GPx) activity assayed using the method of Chiu et al. (1976). Superoxide dismutase (SOD) activity was assayed according to Misra and Fridovich (1972). Total antioxidant capacity (TAC) was determined according to Diamond Biodiagnostic, Egypt.

\section{Statistical analysis:}

The obtained data were analyzed using one-way ANOVA of GLM Procedure of SAS® (SAS Institute, 2000). Significant differences between means were detected using New Duncan Multiple Range - Test (Duncan, 1955).

\section{RESULTS AND DISCUSSION}

\section{Some Productive and reproductive performance traits:}

\section{Feed intake of does}

Total feed intake of does during pregnancy and lactation periods, generally, were affected $(\mathrm{P}<0.01 \& \mathrm{P}<0.05)$ by pomegranate dried waste (PDW) supplementations as compared to control (Table 3). Rabbit doe supplied levels $0.5,1.0$ and $1.5 \%$ with (PDW) in their diet caused to increase $(\mathrm{P}<0.002)$ in feed intake of does by about $13 \%$ in comparison with those does fed the control diet during pregnancy period. On the other hand, does supplied 
Table 3: Some productive $\&$ reproductive performance traits of does fed diets supplemented with different levels of pomegranate dried waste (PDW).

\begin{tabular}{|l|c|c|c|c|c|}
\hline Items & \multicolumn{5}{|c|}{ PDW levels in the diet (\%) } \\
& Control & $\mathbf{0 . 5}$ & $\mathbf{1 . 0}$ & $\mathbf{1 . 5}$ \\
\hline During pregnancy period & \multicolumn{5}{|c|}{ Palue } \\
\hline Doe body weight (g), at mating & 2950 & 2910 & 2990 & 2920 & NS \\
& \pm 48 & \pm 46 & \pm 39 & \pm 40 & \\
\hline Feed intake, (g) & $3510^{\mathrm{b}}$ & $3950^{\mathrm{a}}$ & $4060^{\mathrm{a}}$ & $4080^{\mathrm{a}}$ & 0.01 \\
& \pm 64 & \pm 56 & \pm 39 & \pm 65 & \\
\hline Litter size at birth & $4.98^{\mathrm{c}}$ & $7.82^{\mathrm{b}}$ & $7.98^{\mathrm{b}}$ & $8.42^{\mathrm{a}}$ & 0.01 \\
& \pm 0.41 & \pm 0.67 & \pm 0.57 & \pm 0.37 & \\
\hline Litter weight at birth, (g) & $198.85^{\mathrm{c}}$ & $314.44^{\mathrm{b}}$ & $319.52^{\mathrm{ab}}$ & $335.20^{\mathrm{a}}$ & 0.01 \\
& \pm 18.61 & \pm 22.54 & \pm 20.59 & \pm 21.63 & \\
\hline During lactation period & \multicolumn{5}{|c|}{} \\
\hline Feed intake, (g) & $4902^{\mathrm{c}}$ & $5365^{\mathrm{b}}$ & $5634^{\mathrm{a}}$ & $5660^{\mathrm{a}}$ & 0.05 \\
& \pm 86 & \pm 65 & \pm 76 & \pm 81 & \\
\hline Litter size at weaning & $3.74^{\mathrm{c}}$ & $6.10^{\mathrm{b}}$ & $7.09^{\mathrm{a}}$ & $7.10^{\mathrm{a}}$ & 0.05 \\
& \pm 1.14 & \pm 1.01 & \pm 0.48 & \pm 0.91 & \\
\hline Litter weight at weaning, (g) & $1743.40^{\mathrm{c}}$ & $2493.56^{\mathrm{b}}$ & $2953.8^{\mathrm{a}}$ & $2853.21^{\mathrm{a}}$ & 0.05 \\
& \pm 40.13 & \pm 51.26 & \pm 48.11 & \pm 39.2 & \\
\hline Pre weaning mortality rate, (\%) & $24.9^{\mathrm{a}}$ & $21.9^{\mathrm{b}}$ & $11.2^{\mathrm{d}}$ & $15.7^{\mathrm{c}}$ & 0.0001 \\
& \pm 9.15 & \pm 8.1 & \pm 2.34 & \pm 3.98 & \\
\hline
\end{tabular}

a,b,c Means within a column not sharing similar superscripts are significantly different $(\mathrm{P} \leq 0.05)$.

NS : Not significant $(\mathrm{P}>0.05)$.

with 1.0 and $1.5 \%$ (PDW) in their diet resulted in a significant increase in feed intake during lactation period, followed by those fed $0.5 \%$ in their diets, respectively, as compared to the control group, during summer months.

These declines in the control treatment tend to the effect of high temperature on the thermal receptors that transmit suppressive nerve impulses to the appetite centre coursing a decrease in feed consumption.

Radwan and Abdel - Khalek (2007) suggested that the herb mixture of equal parts of sage, oregano and sweet basal at $0.5 \%$ supplementation level increased both of villi height, crypt depth and absorption area and improved growth and health of rabbits grown under high ambient temperature conditions. The significant increase in feed intake for does treated with PDW may be due to PDW having antioxidant properties (Ghasemain et al., 2006) which delays the start or slow the rate of oxidation reaction in animal cell (Little and Gladen, 1999). So, the consumption of PDW under summer hot conditions helps the animal to improve feed intake and decrease oxidative status through antioxidant 
properties of PDW. Phenolic substances present in these fruit wastes are believed to be behind this effect. They have been implicated in increasing the antioxidative systems, acting as enzyme modulators and metal chelators (Butera et al., 2002 and Edenharder and Grunhage, 2003). These agents inhibit peroxidation reactions and significantly reduce the oxidative stress (Fuhrman and Aviram 2001 and Pari and Saravanan, 2002).

\section{Litter size and weight at birth}

Means of litter size and weight at birth are listed in (Table 3). The rabbit does supplied at level 1.5\% PDW in their diet caused clear to increase $(\mathrm{P}<0.01)$ in litter size by about $40.86 \%$ as compared with those does fed control diet. On the other hand, does supplied at levels 0.5 or $1.0 \%$ PDW in their diet resulted in a significant increase in litter size as compared to the control group. However, there were significant effects among treatment group on litter weight at birth with PDW supplementation, this increase due to the increase the number of bunny at birth. Theses results were agreed with Abdel-Samee, et al (2005), who described that the litter size and weight of rabbits increased $(\mathrm{P}<0.05)$ in summer months than that in winter months for California and NZW rabbits at birth, 21 days of age and at weaning. Abdel-Khalek et al. (2008) indicate that supplied vitamin E in diet rabbits had the highest values of litter size and weight at birth.

Litter size and weight at weaning generally affected $(\mathrm{P}<0.05)$ by pomegranate dried waste (PDW) supplementations compared to control group. The rabbit does supplied at levels 1.0 or $1.5 \%$ (PDW) in their diet caused to increase $(\mathrm{P}<0.05)$ in litter size at weaning by about $47.3 \%$ in comparison with those fed control diet. On the other hand, rabbits doe supplied at level 0.5\% PDW in their diet resulted increased in a significant litter size at weaning (by about $38.7 \%$ ) in comparison with those group fed the control diet. The clear improvement in performance of polyphenol with (PDW) treatments might be due to its protective action against lipid oxidation in the cell membrane (Liebler, 1992). Also, it was important for newborns, which exhibits a greater sensitivity to oxidative damage than adults, and for the development of the immune system in young animals (Debier et al., 2005).

However, litter weight at weaning age for the rabbit does supplied with 0.5 , 1.0 or $1.5 \%$ PDW levels in their diet had been increased $(\mathrm{P}<0.05)$ in comparison with those group fed the control diet. These improvement back to the number of pups per doe, but the reduction in pups weight tend to that young rabbits reared in larger litters have access to less milk, which leads to reduce weight gain (Sezendro, 1999).Vicenye and Garcia- Ximenez (1992), also established that both 
the ability of the doe for milk production and competition between suckling rabbits limits the maximum expression of genetically determined ability for growth. On the other hand, Marai et al. (1996) showed that pups weight gain were lower in summer than in winter by 19,25 and $23 \%$ during the period (0-21), (21$35)$ and (0-35) days of age, respectively.

\section{Pre- weaning mortality rate from birth to weaning:}

Means of pre- weaning mortality rate from birth to weaning age in the treatments groups were 24.9, 21.9, 11.2 and 15.7\%, respectively (Table 3). The differences between the treatments were significant. This result indicated that PDW supplementation reduced mortality rate from birth to weaning age and this reduction may be due to the increase in the defense mechanism system in these treatments. Doe rabbits milk are contain Colostrums is the very first secretion of the mammary glands. It is very nutritious and contains high levels of protein, milk solids, globulins, fats and vitamin A. Most important, it contains antibodies against the diseases to which the doe has immunity. It is critical to feed colostrums for the first three days for maximum protection against disease because the absorption of these antibodies disappears after three days. Immunoglobulin among factors absorbed from milk that have potential for regulating the immune responses of rabbit neonates. All the previous points will reduce in hot months, so the addition of PDW in different levels as a rich source of natural antioxidants in does rabbit diets will help them to protective from oxidative stress.

Dietary polyphenols have been reported to possess potent antioxidant activity by endogenous and exogenous mechanisms. Li et al., (2003) they found that the extract of pomegranate leaves abundant with tannins was demonstrated to be a good gastric protective agent, increase the activity of pepsin, improve the secretion of bile, enhance the intestine peristalsis, inhibit the secretion of gastric acid and dispel intestinal parasite by continual intestinal tract concentration. Besides, pomegranate extract inclusion significantly enhanced the growth of Bifidobacterium breve and Bifidobacterium inantis which conceder a good probiotic essential for good health (Viuda-Martos et al., 2010).

Generally, the current study provide in field evidence that when pomegranate dried waste at different levels $0.1,1.0$ and $1.5 \%$ could have a satisfactory effect on performance of does rabbit since they have a high total antioxidant effect against Oxidants (reactive oxygen species; ROS) that release from the animal that expose to environmental stress (summer season) as indicated in Table 3. 


\section{Milk yield}

Doe rabbits fed basal ration and supplemented with 1.0 and 1.5 pomegranate dried waste showed the best value of milk yield (Table 4). The differences were not significant between control and 0.5\% PDW treatments. However, 1.0 and $1.5 \%$ of PDW supplementation were significantly increased $(\mathrm{P}<0.01)$ the milk yield from birth to 21 and 28 days of lactation (Table 4). These results were similar to those of Marai et al. (1996). Abdel-Khalek et al .(2008) indicated that vitamin $\mathrm{C}$ and $\mathrm{E}$ or compilation had the highest values for milk production during all lactation periods.

Table 4: Milk yield of NZW doe rabbits as affected by pomegranate dried waste supplementations.

\begin{tabular}{|c|c|c|c|c|c|}
\hline Items & \multicolumn{5}{|c|}{ Pomegranate dried waste levels in the diet (\%) } \\
\hline Mill yield (g): & Control & $\mathbf{0 . 5}$ & $\mathbf{1 . 0}$ & $\mathbf{1 . 5}$ & P value \\
\hline $\mathbf{1}^{\text {st }}$ & $70.22^{\mathrm{b}}$ & $77.10^{\mathrm{b}}$ & $90.1^{\mathrm{a}}$ & $88.36^{\mathrm{a}}$ & \multirow{2}{*}{0.01} \\
& \pm 4.0 & \pm 6.11 & \pm 7.8 & \pm 10.1 & \\
\hline $\mathbf{2}^{\text {nd }}$ & $89.11^{\mathrm{b}}$ & $90.65^{\mathrm{b}}$ & $100.04^{\mathrm{a}}$ & $99.69^{\mathrm{a}}$ & \multirow{2}{*}{0.01} \\
& \pm 3.0 & \pm 8.6 & \pm 9.01 & $\pm 8.9^{\mathrm{a}}$ & \\
\hline $\mathbf{3}^{\text {rd }}$ & $109.60^{\mathrm{b}}$ & $119.50^{\mathrm{b}}$ & $144.16^{\mathrm{a}}$ & $135.93^{\mathrm{a}}$ & \multirow{2}{*}{0.01} \\
& \pm 1.8 & \pm 8.9 & \pm 9.1 & \pm 6.8 & \\
\hline $\mathbf{4}^{\text {th }}$ & $80.48^{\mathrm{b}}$ & $99.01^{\mathrm{ab}}$ & $104.36^{\mathrm{a}}$ & $110.23^{\mathrm{a}}$ & \multirow{2}{*}{0.01} \\
& \pm 9.0 & \pm 12.0 & \pm 11.0 & \pm 10.0 & \\
\hline $\mathbf{0 - 2 1}$ days & $89.64^{\mathrm{b}}$ & $95.75^{\mathrm{b}}$ & $111.43^{\mathrm{a}}$ & $108^{\mathrm{a}}$ & \multirow{2}{*}{} \\
& \pm 9.1 & \pm 11.0 & \pm 6.8 & \pm 8.9 & 0.01 \\
\hline $\mathbf{0 - 2 8}$ days & $87.35^{\mathrm{b}}$ & $96.81^{\mathrm{ab}}$ & $109.67^{\mathrm{a}}$ & $108.55^{\mathrm{a}}$ & \\
& \pm 9.8 & \pm 8.6 & \pm 9.0 & \pm 10.01 & 0.01 \\
\hline
\end{tabular}

a,b, Means within a column not sharing similar superscripts are significantly different $(\mathrm{P} \leq 0.05)$.

NS : Not significant $(\mathrm{P}>0.05)$.

\section{Blood biochemical constituents:}

It could be observed that doe rabbits fed different levels $(0.5,1.0$ and $1.5 \%)$ of PDW in diets had significant increase in high density lipoprotein (HDL) cholesterol comparing with rabbits fed basal diet (Table 5). Moreover, all groups administrated with different level of PDW $(0.5,1.0$ and $1.5 \%)$ had a significant decrease in plasma total cholesterol; triglycerides low density lipoprotein (LDL) and very low density lipoprotein (v LDL) as compared with the control group. A high consumption of phenolic compounds has already been found to decrease serum cholesterol and triacylglycerol concentrations in 
Table 5: Blood constituents of NZW doe rabbits as affected by the experimental diets.

\begin{tabular}{|c|c|c|c|c|c|}
\hline \multirow[t]{2}{*}{ Criteria } & \multicolumn{5}{|c|}{ Pomegranate dried waste levels (\%) } \\
\hline & $\mathbf{0}$ & 0.5 & $\mathbf{1 . 0}$ & $\mathbf{1 . 5}$ & P value \\
\hline \multicolumn{6}{|c|}{ Blood plasma constituents } \\
\hline $\begin{array}{l}\text { Total cholesterol, } \\
\text { (mg/dl) }\end{array}$ & $\begin{array}{c}68.33 \\
\pm 4.89^{\mathrm{a}}\end{array}$ & $\begin{array}{c}66.33 \\
\pm 4.76^{\mathrm{b}}\end{array}$ & $\begin{array}{l}64.00 \\
\pm 4.11^{\mathrm{c}}\end{array}$ & $\begin{array}{c}63.67 \\
\pm 4.52^{\mathrm{c}}\end{array}$ & 0.005 \\
\hline Triglycerides, (mg/dl) & $\begin{array}{r}65.10 \\
\pm 3.54^{\mathrm{a}}\end{array}$ & $\begin{array}{r}63.00 \\
\pm 3.46^{\mathrm{b}}\end{array}$ & $\begin{array}{c}61.01 \\
\pm 3.69^{c}\end{array}$ & $\begin{array}{r}51.90 \\
\pm 3.99^{\mathrm{d}}\end{array}$ & 0.0001 \\
\hline HDL- cholesterol, (mg/dl) & $\begin{array}{r}30.27 \\
\pm 5.30^{\mathrm{c}}\end{array}$ & $\begin{array}{c}35.40 \\
\pm 5.18^{b}\end{array}$ & $\begin{array}{c}36.93 \\
\pm 5.53^{\mathrm{b}}\end{array}$ & $\begin{array}{r}40.50 \\
\pm 5.98^{\mathrm{a}}\end{array}$ & 0.0001 \\
\hline LDL - cholesterol, (mg/dl) & $\begin{array}{c}23.84 \\
\pm 1.89^{\mathrm{a}}\end{array}$ & $\begin{array}{c}18.13 \\
\pm 1.85^{\mathrm{b}}\end{array}$ & $\begin{array}{r}14.67 \\
\pm 1.97^{\mathrm{c}}\end{array}$ & $\begin{array}{r}14.59 \\
\pm 2.13^{\mathrm{c}}\end{array}$ & 0.005 \\
\hline V LDL (mg/dl) & $\begin{array}{c}13.8 \\
\pm 0.68^{\mathrm{a}} \\
\end{array}$ & $\begin{array}{c}12.80 \\
\pm 0.69^{\mathrm{ab}}\end{array}$ & $\begin{array}{c}12.40 \\
\pm 0.84^{\mathrm{b}} \\
\end{array}$ & $\begin{array}{c}10.58 \\
\pm 0.59^{\mathrm{c}} \\
\end{array}$ & 0.005 \\
\hline \multicolumn{6}{|c|}{ Blood plasma antioxidant constituents } \\
\hline $\mathrm{TAC}^{1},(\mathrm{mmol} / \mathrm{l})$ & $\begin{array}{c}1.99^{\mathrm{d}} \\
\pm 0.02\end{array}$ & $\begin{array}{c}2.38^{\mathrm{c}} \\
\pm 0.02\end{array}$ & $\begin{array}{l}2.55^{\mathrm{b}} \\
\pm 0.04\end{array}$ & $\begin{array}{l}2.66^{\mathrm{a}} \\
\pm 0.05\end{array}$ & 0.0001 \\
\hline SOD $^{2}$, units / L(u/l) & $\begin{array}{l}23.5^{\mathrm{b}} \\
\pm 1.63\end{array}$ & $\begin{array}{c}35.98^{\mathrm{a}} \\
\pm 2.43\end{array}$ & $\begin{array}{l}36.10^{\mathrm{a}} \\
\pm 1.96\end{array}$ & $\begin{array}{l}36.48^{\mathrm{a}} \\
\pm 2.64\end{array}$ & 0.0001 \\
\hline $\mathbf{G P x}^{3},(\mathbf{u} / \mathbf{l})$ & $\begin{array}{l}455^{\mathrm{c}} \\
\pm 40.1\end{array}$ & $\begin{array}{c}673^{\mathrm{b}} \\
\pm 45.6\end{array}$ & $\begin{array}{c}698^{\mathrm{b}} \\
\pm 48.7\end{array}$ & $\begin{array}{c}896^{\mathrm{a}} \\
\pm 42.2\end{array}$ & 0.001 \\
\hline TBARS $^{4},(\mu \mathrm{mol} / \mathrm{ml})$ & $\begin{array}{c}1.17^{\mathrm{a}} \\
\pm 04\end{array}$ & $\begin{array}{c}0.89^{\mathrm{b}} \\
\pm 02\end{array}$ & $\begin{array}{c}0.82^{\mathrm{c}} \\
\pm 01\end{array}$ & $\begin{array}{c}0.75^{\mathrm{d}} \\
\pm 03\end{array}$ & 0.0001 \\
\hline
\end{tabular}

a,b,c Means within a column not sharing similar superscripts are significantly different $(\mathrm{P} \leq 0.05)$. NS : Not significant $(\mathrm{P}>0.05)$.

(1) $\mathrm{TAC}=$ Total antioxidant capacity. (2) SOD = Superoxide dismutase

(3) GSH-Px = Glutathion peroxidase (4) TBARS= Thiobarbituric acid

rat (Afaf et al., 2000). Meanwhile, groups supplemented with 1.0 and $1.5 \%$ had intermediate values. Dietary supplementation with nutrients rich in antioxidants was associated with inhibition of atherogenic modifications to LDL, macrophage foam cell formation, and atherosclerosis. Aviram et al., (2000) reported that dietary supplementation with nutrients rich in antioxidants was associated with inhibition of atherogenic modifications of LDL, macrophage foam cell formation and atherosclerosis. Also, Li et al., (2006) who reported that pomegranate peel extract appeared to have more potential as a health supplement richer in natural antioxidants than the pulp extract. These results are agreed with Esmaill Zadeh et al. (2006) they reported that consumption of concentrated pomegranate juice 
for diabetic patient with hyperlipidemia significantly decreased in total cholesterol $(\mathrm{P}<0.006)$ and had no significant changes in serum HDL. Also, Labib (2009) reported that all hypercholestrolemic groups administrated with different level of pomegranate peel powder $(5,10$ and $15 \%)$ or administrated with pomegranate peel extracted (1,2 and 3\%) had a significant decrease in serum low density lipoprotein LDL, very V LDL, lipid peroxidation and atherogenic index compared with hypercholesterolemic rats (control positive).

\section{Blood plasma antioxidant constituents:}

It is clear that, the high cholesterol diet used in this experiment could induce many of the health hazards reported by different investigators. This shows how important it is to find a way or a mean to avoid these health complications. The beverages produced in this study, which was prepared from the vegetable or fruit wastes can be that mean. These beverages proved to contain considerable number and quantities of the polyphenolic antioxidants (El-Shobaki et al., 2011) which are believed to participate in the prevention of these health hazards. Pomegranate peels contain of $(3,164 \%$ total phenols, w/ w.) could be a valuable source of natural phenolic antioxidants.

Blood plasma TAC, SOD, and GPx activities significantly increased with increasing pomegranate peel content while it decreased TBARS activity of blood plasma (Table 5). These results are parallel with Bagri et al. (2008) about the effects of administration of Punica Granatum aqueous extract at doses of 250 $\mathrm{mg} / \mathrm{kg}$ and $500 \mathrm{mg} / \mathrm{kg}$ for 21 days on diabetic rats, resulted were in a significant reduction in fasting blood glucose, TC, TG, LDL-C, V LDL-C and tissue LPO levels coupled with elevation of HDL-C, GSH content and antioxidant enzymes in comparison with diabetic control group.

Hermes-Lima et al. (1998) proposed that the activation of antioxidant defenses, in which the actual production of oxyradicals should decrease, is a preparative mechanism against oxidative stress caused by physiological stress situations. Erisir et al. (2009) evaluates the oxidant and antioxidant status for pregnancy in ewes and found decreased CAT activities and elevated GSH concentrations and GSH-Px activities after the 1st month of pregnancy in ewes.

Conclusively, from these results indicate that the addition of pomegranate dried waste at level 5.0 or $1.0 \%$ of the feed doe New Zealand White rabbits during pregnancy and lactation periods improved milk production and most of the reproductive performance, had a beneficial effect on blood cholesterol and the antioxidative status of heat stressed does rabbit plasma, under Egyptian conditions. 


\section{REFERENCES}

Abdel-Khalek A.M., Selim N.A., El-Medany Sh.A., Nada S.A. (2008). Response of doe rabbits to dietary antioxidant vitamins $\mathrm{E}$ and $\mathrm{C}$ during pregnancy andlactation. 9th World Rabbit Congress - June 10-13, 2008 Verona - Italy. Pp (59-524).

Afaf, K. E., Jan, F., Alexander, R. and Siv, T.(2000): Effects of dietary phenolic compounds on tocopherol, cholesterol and fatty acids in rats. Lipids; 35: 427-35.

AOAC International, (2003). Official Methods of Analysis of AOAC International. 2nd Revision, 17th Edn., Association of Analytical Communities, Gaithersburg, MD., USA.

Aviram M., and Dornfeld L. (2001): Pomegranate juice consumption inhibits serum angiotensin converting enzyme activity and reduces systolic blood pressure, Elsevier, Atherosclerosis, 158: 195 -198.

Aviram, M., L. Dernfeld, M. Rosenblat, N. Volkova, M. Kaplan, R. Coleman, T. Hayek, D. Presser and B. Fuhrman, (2000): Pomegranate juice consumption reduces oxidative stress, atherogenic modifications to LDL and platelet aggregation: studies in humans and in atherosclerotic apolipoprotein E-deficient mice. Am. J. Clin. Nutr., 71: 1062-1076.

Bok, S.H., S.A. Lee, Y.B. Park, K.H. Bae, K.H. Son, T.S. Jeong and M.S. Choi, (1999): Plasma and hepatic cholesterol and hepatic activities of 3hydroxy-3- methyl-glutaryl-CoA reductase and acyl CoA: cholesterol transferase are lower in rats fed citrus peel extract or a mixture of citrus bioflavonoids. J. Nutr., 29: 1182-1185.

Butera, D., Tesoriere, L., Di Gaudio, F., et al., (2002), "Antioxidant activities of sicilian prickly pear (Opuntia Picus inca) fruit extracts and reducing properties of its betalains: betanin and indicaxan. J. Agric. Food Chem. 50, 6895-6901.

Bagri P, Ali M, Aeri V, Bhowmik M. and Sultana S.(2009). Antidiabetic effect of Punica Granatum flowers: effect on hyperlipidemia, pancreatic cells lipid peroxidation and antioxidant enzymes in experimental diabetes. Food, Chem, Toxicol., 47(1):50-4. Epub 2008 Oct 4.

Castellini C., Dal Bosco A., Bernardini M. 2000. Improvement of lipid stability of rabbit meat by vitamin $\mathrm{E}$ and $\mathrm{C}$ administration. J. Sci. Food Agric., 81: 46-53.

Cheeke, P.R. (1987): Rabbit Feeding and Nutrition. Orlando: Academic Press, Inc. Harcourt, Brace, Jovanovich, Publishers. 
Cheesman K., and Slater T. (1993). An introduction to free radical biochemistry. British Medical Bulletin, 49: 481-493.

Chiu, D.T.Y., Stults, F.H. and Tappel, A.L. (1976): Purification and properties of rat lung soluble glutathione peroxidase. Biochimica et Biophysica Acta, 445: 558-566.

Debier C., Pottier J., Goffe Ch. Larondelle Y. (2005). Seventh International Workshop in the Biology of Lactation in Farm Animals. Livestock Production Sci., 98 (1), 135-147.

Duncan, D.B. (1955): Multiple ranges and multiple F-tests. Biometrics, 11: 1-42.

Edenharder, R. and Grunhage, D., (2003), "Free radical scavenging abilities of flavonoids as mechanism of protection against mutagenicity induced by terbutyl hydroperoxide or cumene hydroperoxide in Salmonella tyuphimurium TA102.", Mutat Res., 540: 1-18.

El-Shobaki F.A, Kassem, Seham, S Abdel-Kader, Madiha M. (2011): Innovative forms of beverages with health value from vegetable and fruit wastes. International Journal of Academic Research; 3 (3), Part II: 582588.

Esmaill Zadeh, A., F. Tabaz, I. Gaieni, H. Alavi-Majd and L. Azadbakht, (2006): Cholesterol-lowering effect of concentrated pomegranate juice consumption in type II diabetic patients with hyperlipidemica. Int. J. Vitam. Nutr. Res., 76: 147-51.

Erisir, M.; Benzer, F.; Kandemir, F M. (2009). Changes in the rate of lipid peroxidation in plasma and selected blood antioxidants before and during pregnancy in Ewes. Acta Vet. Brno, 78: 237-242.

FAOSTAT-FAO. Statistical database. (2010): Food and Agriculture Organization of the United Nations, Codex Alimentarius Commision: Tunis, Tunesia. http://www.fao.org.

Fernández, C., Cobos, A. and Fraga, M.J. (1994). The effect of fat inclusion on diet digestibility in growing rabbits. Journal of Animal Science, 72: 15081515 .

Finzi A, Macchioni P and Kuzminsky G 1994 Circadian cycle of rabbit body temperature in the hot season. Proceedings of the 1st International Conference on Rabbit Production in Hot Climates, Cairo , 8.471-8.474.

Fridewald, W.T., R.I. Leve and D.S. Fredrickson, (1972): Estimation of the concentration of low density lipoprotein. Clin. Chem., 18: 499-502.

Fuhrman, B. and Aviram, M., (2001), "Flavonoids protect LDL from oxidation and attenuate atherosclerosis.", Curr. Opin. Lipidoluhrman; 12: 41-8. 
Ghasmian, A., Mehrabian, S. and Majd, A., (2006). Peel extracts of two Iranian cultivars of pomegranate (Punica granatum) have antioxidant and antimutagenic activities. Pakistan Journal of Biological Sciences, 9: 14021405.

Hermes-Lima M., Storey J.M., Storey K.B. (1998): Antioxidant defenses and metabolic depression. The hypothesis of preparation for oxidative stress in land snails. Comp Biochem. Physiol. B-Biochem. Mol. Biol., 120: 437-448.

Kirschvink N., Moffart B., Lekeux P. (2007). The oxidant/antioxidant equilibrium in horses. The Veterinary Journal, 177:178-191.

Kobayashi T., Tsunawaki S., Seguchi H. 2001. Evaluation of the process for superoxide production by NADPH oxidase in human neutrophils: evidence for cytoplasmic origin of superoxide. Redox Report Comm. in Free Radical Res., 6: 27-36.

Labib, F. A. H.. (2009): Effect of pomegranate (Punica Granatum) peels and It's extract on obese hypercholesterolemic Rats. Pakistan Journal of Nutrition , 8 (8): 1251-1257.

Liebler D. (1992). Peroxyl radical trapping reactions of $\alpha$-tocopherol in biomimetic systems. In: Packer, L. and Fuchs, J.Editors, Vitamin E in Health and Disease, Marcel Dekker, New York, USA, pp. 85-97.

Lukefahr S., Hohenboken W., Cheeke P., Patton N. (1983). Characterization of straight bred and crossbred rabbits for milk production and associative traits. J. Animal Sci., 1100-1107.

Lykkesfeldt J., and Svendsen O. (2007). Oxidants and antioxidants: oxidative stress in farm animals. Vet. Journal, 173(3): 502-511.

Li, D.G., Zhang, Z. M., Chen, X. J. (2003). Study on the influence of aqueous extract of leaves of Punica granatum on the secretion of gastric acids and experimental gastric ulcer. Chinese Journal of Preventive Medicine , 19: 23-24.

Li, Y. G.; Changjiang, Y. J.; Wei, J.; Xu, J. and Cheng, S. (2006): Evaluation of antioxidant properties of pomegranate peel extract in comparison with pomegranate pulp extract. Food Chemistry, 96: 254-260.

Little RE, Gladen BC 1999: Levels of lipid peroxides in uncomplicated pregnancy: a review of the literature. Reprod Toxicol ., 13: 347-352.

Maha H. Mahmoud, Seham S. Kassem, Madiha M. Abdel- Kader, F.A. ElShobaki. (2011): How to reduce weight and keep healthy. International Journal of Academic Research, Vol. 3 (6) November, 2011, pp (26-32). 
Makled, M. N.; Sharara, H. H. and Abd El-Fattah, H. (2003): Tolerance of California rabbits to different levels of dietary tannic acid. Egyptian Journal of Poultry Science, 23 (III): 641-654.

Marai, I.F.M.;Ayyat, M.S.; Gabr, H.A. and Abdel-Moneum, U.M.(1996). Effect of summer heat stress and its amelioration on production performance of New Zealand White broiler adult female and male under Egyptian condition. 6th World Rabbit Congress, 2 : 197-208.

Marai I.F.M., Habeeb, A. A. M. and Gad A. E. (2002). Rabbits' productive, reproductive and physiological performance traits as affected by heat stress: a review. Livestock Production Science, 78: 71-90.

Misra, H.P. and Fridovich, I. (1972):The role of superoxide anion in the autoxidation of epinephrine and a simple assay for superoxide dismutase. Journal of Biological Chemistry, 247: 3170-3175.

NRC. (1977): National Research Council:Nutrient requirements of Rabbits. ( $2^{\text {nd }}$ rew.ed.). National Academy of science, Washington, DC. USA.

Pari, L. and Saravanan, G., (2002), "Antidiabetic effect of agent db, and herbal drug in alloxan-induced diabetes mellitus.", Comp Biochem Physiol., 131: $19-25$.

Radwan, N.L. and A.M. Abdel - Khalek, 2007. Response of summer stressed growing rabbits to some dietary growth promoters. Tartu Estonia "Animal Health, Animal Welfare And Biosecurity", 1: 350-358.

SAS, (2000). User's Guide: Statistics, Version 8.1. SAS Institute Inc. Cary, NC.

Szendro, Z.; Jovanczai, Z.; Theau-Clement, M.; Radnal, I.; Biro- Nemeth, E. and Milistis, G.(1999).The effect of doe-litter separation on productive performance in rabbit does and their kits. World Rabbit Sci, 7: 165-169.

Seham, S. Kassem, Maha, H. Mahmoud, Madiha, M. Abdel- Kader and ElShobaki, F. A. (2011): Evaluation of the health value of some beverages prepared from vegetable and fruit wastes. Journal of American Science, 7 (9): 328-339.

Singh, R.P.; Murthy, K.N.C and Jayaprakasha, G.K. (2002): Studies on theantioxidant activity of pomegranate peel and seed extracts using in vitro models. J. of Agric. and Food Chemistry, 50: 81-86.

Singleton, V.L. and Rossl. J.A. (1965). Colorimetry of total phenolics with phosphomolybdic-phosphotungstic acid reagents. American Journal of Enology and Viticulture, 16:144-58.

Smith, J.T. and Mayer, D.T. (1955): Evaluation of sperm concentration by the hemacytometer method. Comparison of four counting fluids. Fertility and Sterility, 6: 271-275. 
Tachibana, H, (2011). Green tea polyphenol sensing. Proc Jpn Acad Ser B Phys Biol Sci., 2011 March 11; 87(3): 66-80.

Tappel, A.L. and Zalkin, H. (1959): Inhibition of lipid peroxidation in mitochondria by vitamin E. Archives of Biochemistry and Biophysics, 80: 333-336.

Thring TS, Hili P, Naughton DP. (2009): Anti-collagenase, anti-elastase and anti-oxidant activities of extracts from 21 plants. BMC Complementary and Alternative Medicine, 9: 17-27.

Tortora GJ and Grabowski SR. (1996): Principles of Anatomy and Physiology - 8th Edition, Harper Collins, NY.

Tripathi K (1994): Essential of Medical Pharmacology. New Delhi, Jaypee Brothers Medical Publishers, pp. 187.

Vicenye,J.S.; Garcia- Ximenez, F. (1992): Growth limitations of suckling rabbits. Proposal of a method to evaluate the numerical performance of rabbit does until weaning. J. Appl. Rabbit Res., 15:848-855.

Viuda-Martos, M., Fern', J., Andez-L'Opez, and P'erez-'Alvarez, J.A. (2010). Pomegranate and its Many Functional Components as Related to Human Health: A Review. Comprehensive Reviews in Food Science and Food Safety, 9:635-654.

Yousef, M.I., (2005): Reproductive performance, blood testosterone, lipid peroxidation and seminal plasma biochemistry of rabbits as affected by feeding Acacia saligna under subtropical conditions. Food Chem. Toxicol., 43: 333-9.

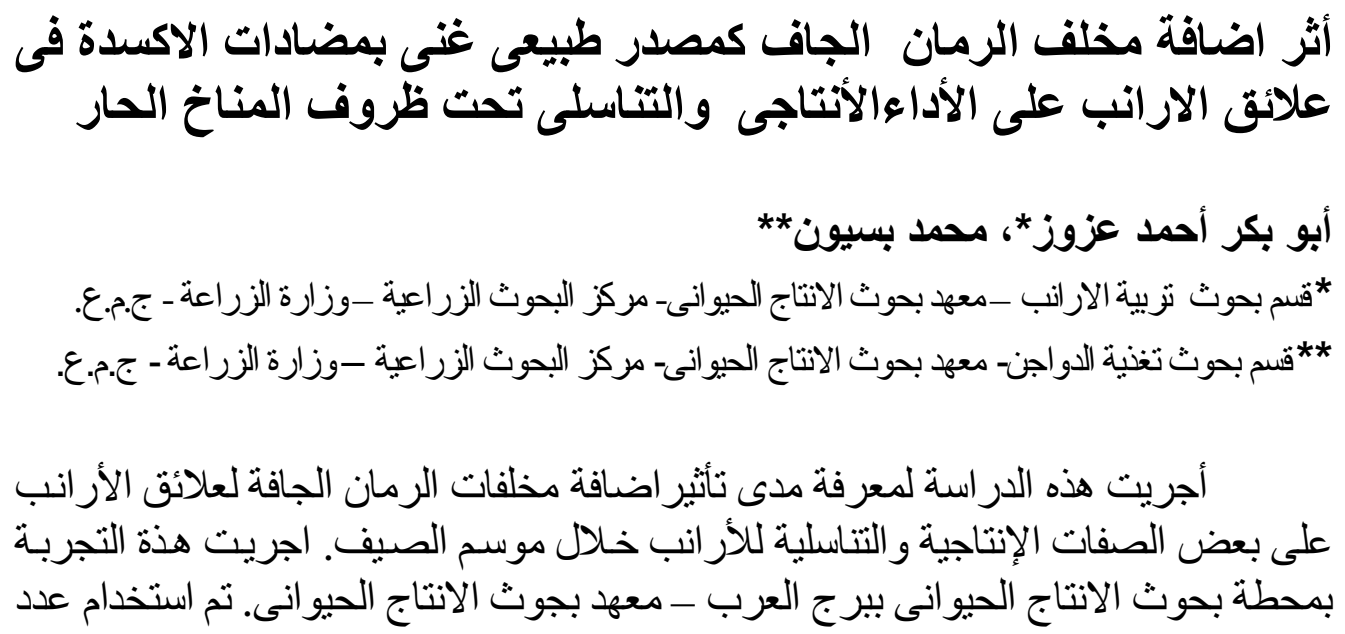




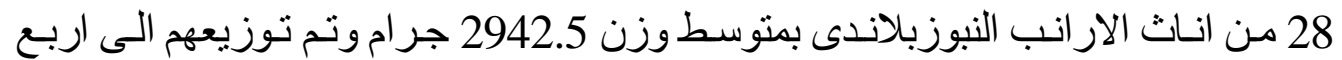

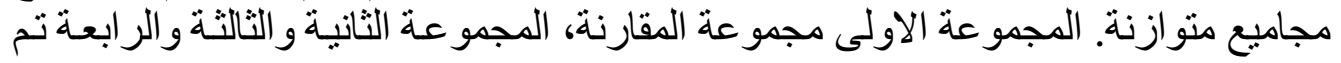

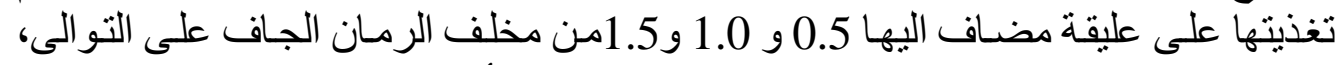

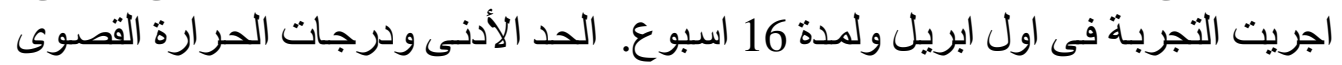

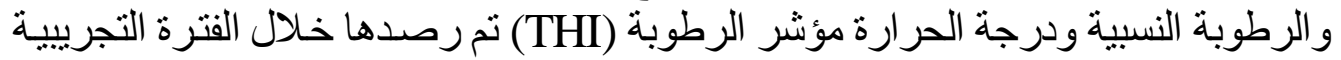

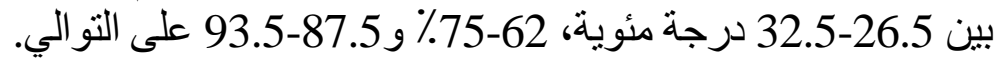

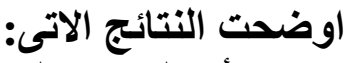

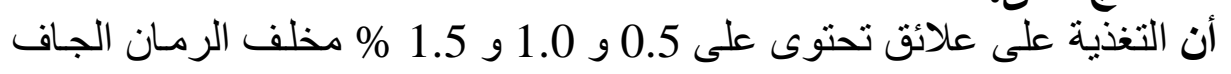

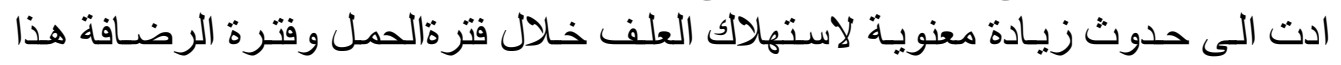

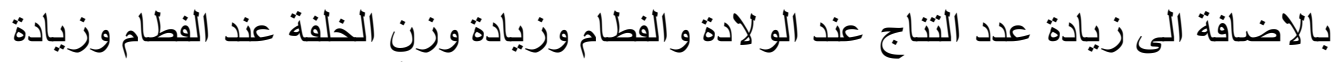

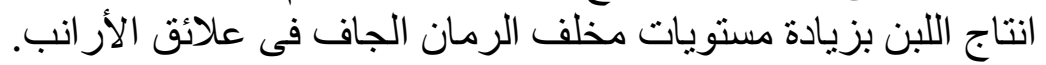

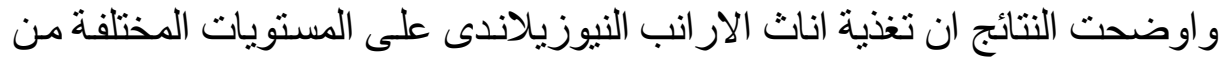

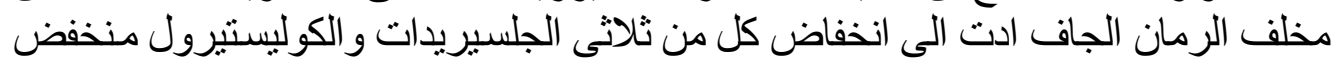
الكثافة بالام مقارنة بمجمو عانة المقارنة.

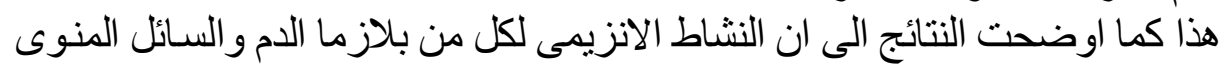

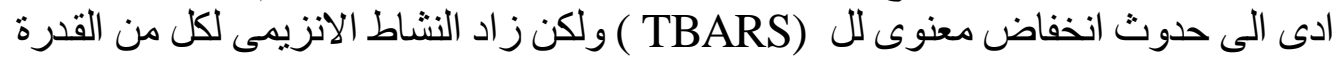

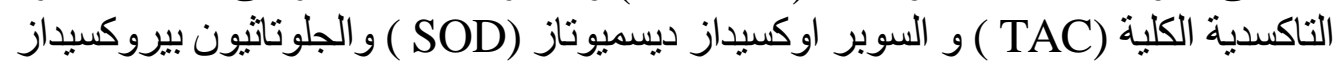
مقارنة بالمجمو عة المقارنة.

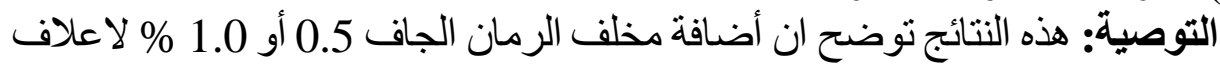

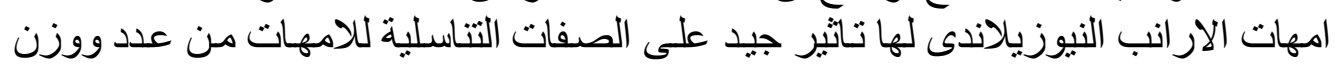

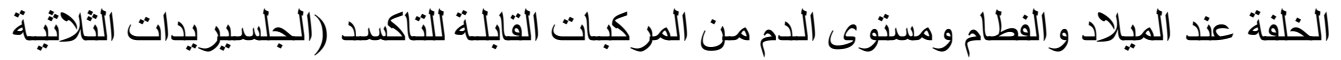

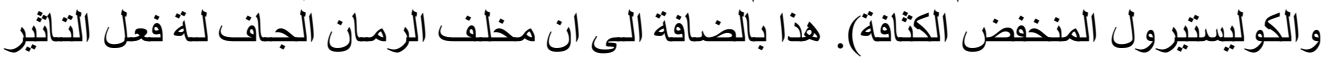

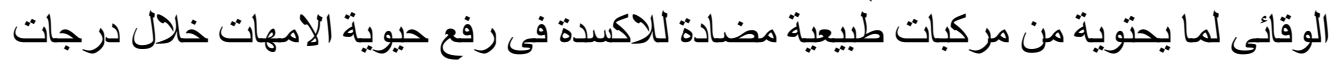

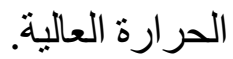

